\title{
Control of Melanoma Morphogenesis, Endothelial Survival, and Perfusion by Extracellular Matrix
}

\author{
Andrew J. Maniotis, Xue Chen, Christopher Garcia, Phillip J. DeChristopher, \\ Ding Wu, Jacob Pe'er, and Robert Folberg \\ Department of Pathology (AJM, XC, CG, PJD, DW, RF), University of Illinois at Chicago, Chicago, Illinois; and \\ Department of Ophthalmology (JP), Hadassah-Hebrew University Medical Center, Jerusalem, Israel
}

\begin{abstract}
SUMMARY: The morphogenetic properties of endothelial cells and melanoma cells were tested under varying matrix quantities and distributions and under constant and saturating levels of growth factors. Aggressive melanoma cells self-assembled into cords vasculogenically only when seeded on thin matrices: nonaggressive melanoma cells did not mimic endothelial cell behavior under any matrix thickness. When buried in matrix, however, aggressive melanoma cells generated looping patterns that contained tumor cells and matrix. These patterns were different topologically and compositionally from cord-like structures or blood vessels but were nevertheless capable of conducting dye by microinjection or passive diffusion. When seeded on three-dimensional cultures of nonaggressive nonpattern-forming melanoma cells, prelabeled endothelial cells attached to, penetrated through, and survived for 2 weeks but failed to form vasculogenic cords. In cocultures containing aggressive melanoma cells, endothelial cells survived briefly but formed short cords only in contact with looping patterns formed by the aggressive tumor cells. Time-lapse recording showed that endothelial cells were lysed upon direct contact with aggressive melanoma cells. Looping patterns identified in human tissue samples were composed ultrastructurally of electron-dense material on either side of a layer of tumor cells; scattered red blood cells were seen in this central cellular layer. By immunohistochemistry, patterns labeled with laminin and fibrinogen colocalized to these looping laminin-positive patterns, suggesting the presence of plasma within these patterns from contiguous leaky tumor vessels. These observations are consistent with the perfusion of these patterns in vitro and with repeated demonstrations of the colocalization of intravenous tracers to looping laminin patterns in animal xenograft models by independent groups. Thus, the distribution and localized quantity of extracellular matrix in aggressive melanomas contributes to the regulation of tumor cell morphogenesis, modulates interactions between tumor cells and endothelial cells, and may contribute to an extravascular matrix-directed circulation. (Lab Invest 2002, 82:1031-1043).
\end{abstract}

$H$ ighly aggressive cancers are locally destructive of the regional host microenvironment but also require a blood supply for sustained growth. Tumors may acquire a blood supply by angiogenesis (Folkman, 1995) or by incorporating (Thompson et al, 1987) or co-opting (Holash et al, 1999) pre-existing blood vessels. Some have suggested that the more aggressive the tumor, the more robust the angiogenic response (Weidner, 1998). However, herein lies a paradox: by what mechanisms are highly aggressive tumors both destructive of the local microenvironment and simultaneously permissive of the penetration of angiogenic vessels and the establishment of an endothelial microcirculation? In animal models, the vascular density in the tumor interstitium surrounding the tumor may be far greater than the vascular density within the tumor (Nasu et al, 1999), and recently, the density of blood vessels within the cellular compartment of human cutaneous melanomas was shown to

DOI: 10.1097/01.LAB.0000024362.12721.67

Received March 22, 2002.

This work was supported by NIH Grants EY10457 and CA83137. Address reprint requests to: Dr. A. J. Maniotis, Department of Pathology (MC847), University of Illinois at Chicago, 1819 W. Polk Street (446 CMW), Chicago, Illinois60612.E-mail: Amanioti@uic.edu be significantly less than in the dermis surrounding the tumor (Straume and Akslen, 2001).

Maniotis et al (1999) reported that uveal and cutaneous melanoma cells that were highly invasive in a membrane invasion culture system (MICS) (Hendrix et al, 1987), deformed floating collagen gels and formed looping patterns that were positive with the periodic acid-Schiff (PAS) stain in three-dimensional cultures on type I collagen and Matrigel. These aggressive melanoma cells generated these patterns independent of endothelial cells and fibroblasts. In vitro, these PAS-positive patterns conducted dye after microinjection. This observation, coupled with the report from a xenograft model of melanoma that looping patterns labeled with heparan sulfate proteoglycan and laminin conducted tracer within seconds after injection into the animal's microcirculation (Potgens et al, 1996), led to the hypothesis that these PAS-positive patterns might contribute to a microcirculation in human melanomas.

Melanoma cells that were poorly invasive in the MICS assay did not deform floating collagen gels and did not form PAS-positive patterns in identical threedimensional cultures even after exposure to conditioned media from the aggressive cell cultures, soluble factors, and hypoxic regimens. The relationship between the pattern-forming capabilities of tumor cells in 
vitro and behavior associated with an aggressive phenotype (eg, invasiveness and deformation of collagen gels) was further strengthened by the repeated observations that looping PAS-positive patterns, identical topologically to those generated in vitro, are strongly associated with death from metastatic uveal (Folberg et al, 1993; Makitie et al, 1999a; Sakamoto et al, 1996; Seregard et al, 1998) and cutaneous melanoma (Thies et al, 2001; Warso et al, 2001) and are detected histologically in metastases (Rummelt et al, 1998).

Although uveal melanomas certainly contain blood vessels (Rummelt et al, 1994) (they do not contain lymphatics; Clarijs et al, 2001), vessels are not typically numerous in zones of the tumor where PASpositive patterns are present (Folberg et al, 2000; Makitie et al, 1999b; Maniotis et al, 1999) despite a lack of necrosis and, presumably, where the aggressive tumor cell population that generates these patterns is established. These observations support the hypothesis that the presence of pattern-generating aggressive melanoma cells may contribute to a limited extravascular circulation in regions of the tumor where they are present.

Because matrix quantity regulates the growth, differentiation, and survival of endothelial cells (Folkman et al, 1989; Ingber and Folkman, 1989; Ingber et al, 1987), it is possible that matrix quantity also regulates the morphologic behavior of aggressive melanoma cells and their interactions with endothelial cells. We therefore compared the behavior of cultured uveal melanoma cells in vivo under varying matrix quantities and saturating amounts of growth factors with endothelial cell behavior under identical conditions, and we studied the interactions between these cells in coculture. The findings from these in vitro and in vivo experiments were then compared with human tumor tissue samples.

\section{Results}

Comparing the Behavior of Endothelial Cells and Melanoma Cells In Vitro: The Effects of Matrix Thickness

The in vitro characteristics of melanocytic cell lines used in this study were reported previously (Maniotis et al, 1999) and are summarized in Table 1. Cell lines were designated as aggressive if they showed high invasive potential in the MICS assay and deformed floating collagen gels. The behavior of these cell lines was compared with the behavior of a variety of endothelial cell types (pulmonary, dermal, and brain microvascular cells, human umbilical vein endothelial cells, aortic endothelial cells, and endothelial cells derived from hemangioma) under four culture conditions: (1) serum-soluble matrix permitting only the attachment of cells to other cells; (2) serum proteins adsorbed to a rigid surface; (3) a thin layer of polymerized matrix (50 to $100 \mu \mathrm{m}$ ) permitting cells to penetrate and remodel the matrix without becoming embedded; and (4) thick matrix (100 $\mu \mathrm{m}$ to $1 \mathrm{~mm}$ in thickness) in which cells were completely embedded. The reactions of
Table 1. In Vitro Characteristics of Melanocytic Cell Lines

\begin{tabular}{lcc}
\hline Culture designation & $\begin{array}{c}\text { Invasive } \\
\text { potential }\end{array}$ & $\begin{array}{c}\text { Deformation } \\
\text { of floating } \\
\text { collagen gels }\end{array}$ \\
\hline UMEL-1 (normal choroid) & $\begin{array}{c}\text { Poor } \\
(0.9 \pm 0.008)\end{array}$ & - \\
OCM-1A (primary) & Poor & - \\
C918 (primary) & $(2.2 \pm 0.09)$ & \\
High & + \\
M619 (primary) & $(12.9 \pm 0.31)$ & \\
& High & + \\
MUM-2B (metastasis to liver) & $\begin{array}{c}\text { High } \\
\text { (12.7 } \pm 0.4)\end{array}$ & + \\
& $(13.3 \pm 0.6)$ & \\
\hline
\end{tabular}

Invasive potential (Seftor et al, 2002) was calculated as the percentage of cells capable of invading a collagenous matrix-coated polycarbonate membrane over 24 hours within a membrane invasion culture system compared with the total number of cells seeded ( $\pm \mathrm{SE} ; n=6$ wells per measurement and run in duplicate experiments).

endothelial cells and melanoma cells to these conditions of increasing matrix quantity are illustrated in Figure 1 and summarized in Table 2.

When seeded with serum alone at high density in shaker flasks, neither endothelial cells nor nonaggressive melanoma cells formed large aggregates regardless of the quantity and type of soluble growth factors added (Fig. 1, A and B), but aggressive melanoma cells commonly formed aggregates from $1 \mathrm{~mm}$ (Fig. 1C) to $10 \mathrm{~mm}$ in diameter (Fig. 1D) in 2 to 3 days. These aggregates maintained a stable size for 3 weeks. The center of these large aggregates became necrotic consistently (Fig. 1E).

5 When cells were cultured in the presence of matrix adsorbed to one rigid surface, a variety of endothelial cells seeded at confluent density with serum proteins adsorbed on flat tissue culture substrates formed cobblestone monolayers (Fig. 1F) as expected. Under identical conditions, nonaggressive melanoma cells formed neither cobblestone monolayers nor aggregates (Fig. 1G). By contrast, aggressive melanoma cells plated under identical conditions aggregated into clusters of several hundred cells spontaneously (Fig. $1 \mathrm{H})$. This phenotype was stable over 2 years.

When endothelial cells were cultured on a thin layer of matrix, they formed cords (Fig. 1, I and J), and when a thin layer of matrix was applied in patterns or in parallel streaks (Chen et al, 1997; Ingber et al, 1994; Singhvi et al, 1994), the endothelial cells formed cords only along the matrix (Fig. 1J); cords were not formed in the absence of matrix regardless of saturating amounts of growth factors including basic fibroblast growth factor, transforming growth factor- $\beta$, vascular endothelial growth factors, conditioned media derived from nonaggressive and aggressive melanoma cells, platelet-derived growth factor, or nondefined factors in serum (Folkman and Moscona, 1978). Under identical culture conditions, nonaggressive melanoma cells formed small spatially separated aggregates and did not form cords (Fig. 1K); but aggressive melanoma 


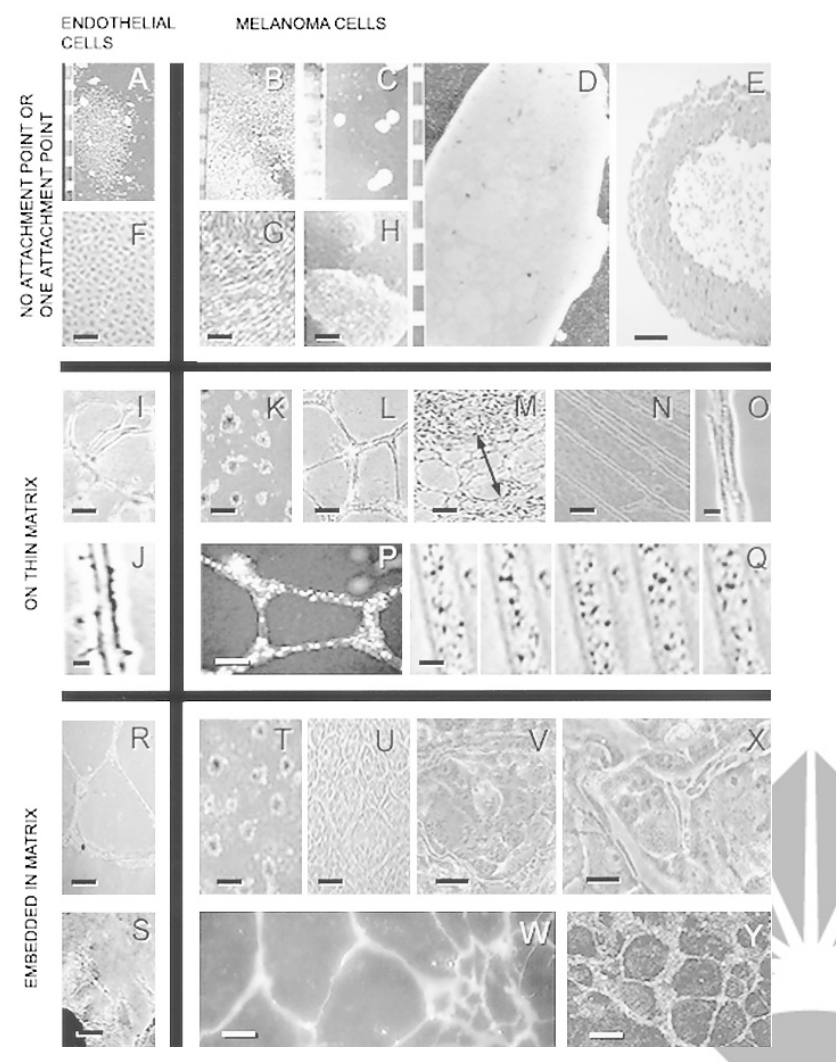

Figure 1.

Growth and morphogenetic potential of isolated endothelial cells and melanoma cells on increasing quantities of matrix. A to $E$, Aggregation potential of endothelial cells in isolation and melanoma cells in isolation without attachment to matrix and with growth factors held constant. A, Microvascular endothelial cells (MECs) forming small aggregates. B, Nonaggressive melanoma cells under identical conditions. $C$, One-millimeter aggregates of aggressive melanoma cells. D, Metastatic melanoma cells (MUM-2B) under the same conditions. E, PAS-stain of aggregate shown in D. F to $\mathrm{H}$, Comparing the self-association of endothelial cells and melanoma cells on serum proteins adsorbed to a rigid substratum. F, MECs on adsorbed serum proteins; G, nonaggressive melanoma cells; $\mathrm{H}$, metastatic melanoma. I to $\mathrm{Q}$, Selfassociative and morphogenetic potential of endothelial cells and melanoma cells on thin $(30-50 \mu \mathrm{m})$ polymerized matrices made of Matrigel and in the presence of serum and exogenous growth factors. I, MECs. J, Oriented cord of MECs. The endothelial cells develop tubes only along the inscribed lines of matrix. K, Nonaggressive melanoma. L, Aggressive melanoma cells on nonoriented matrix. M, Networking cords of aggressive melanoma. Double arrow points to edges of inscribed matrix. N, Parallel cords of aggressive melanoma cells on oriented matrix in the presence of TNP-470. 0 , Higher magnification of metastatic melanoma cord formed in the presence of TNP-470 on oriented matrix. P, Melanoma cells labeled with bisBenzimide are present within the tumor cell cords. Q (1-5), Brownian movement during 5 seconds after injection of carbon black into a melanoma cord. R to $\mathrm{Y}$, Comparison of endothelial cells and melanoma cells embedded in matrix. R, MEC vasculogenesis; $\mathrm{S}$, angiogenesis from everted embedded rat aorta; $\mathrm{T}$, nonaggressive melanoma; $\mathrm{U}$, aggressive melanoma, early culture; $\mathrm{V}$, matrix-embedded aggressive-melanoma-cell amalgam, late culture; $W$, microinjection of these amalgams in late culture; $X$, aggressive melanoma cells in collagen gel, late culture; $Y$, incubation of dye with amalgams. White and black bars in A to D denote millimeters. Bar in $\mathrm{E}=90 \mu \mathrm{m}$; bars in $\mathrm{F}$ to $\mathrm{H}, \mathrm{I}, \mathrm{K}$ to $\mathrm{N}, \mathrm{R}$ to $\mathrm{U}, \mathrm{W}$, and $\mathrm{Y}=50 \mu \mathrm{m}$; bars in $\mathrm{P}=20 \mu \mathrm{m}$; bar in $\mathrm{V}=30 \mu \mathrm{m}$; bar in $\mathrm{J}$ and $0=5 \mu \mathrm{m}$; bar in $Q=2 \mu \mathrm{m}$.

cells, under identical conditions, formed networks of cords (Fig. 1L), similar in appearance to endothelial cell networks of cords (Fig. 11). When a thin layer of matrix was applied in parallel streaks, aggressive melanoma cells, like endothelial cells, formed cords only where matrix was applied to the substratum; only one cell diameter beyond the confines of the restricted matrix, aggressive tumor cells formed a monolayer (Fig. 1M). Parallel cords of melanoma cells could be induced if special care was taken to orient the thin matrix coating in one direction (Fig. 1, J, N, and O).

TNP-470, a derivative of fumagillin, has been shown to block the growth and morphogenesis of endothelial cells (Kusaka et al, 1994). The formation of cords by aggressive melanoma cells was not blocked by TNP470 at concentrations that completely blocked endothelial cord formation (Ingber et al, 1990; Kusaka et al, 1994) (Fig. 1, N and O). Cords formed by aggressive melanoma cells on thin matrix were solid in early cultures: when cultured aggressive melanoma cells were prelabeled with bisBenzimide, tumor cells were identified within the tumor cell-generated cords (Fig. 1P). However, in mature cultures at 2 weeks, it was possible to microinject fluid into the melanoma cell cords and to demonstrate Brownian motion of carbon black particles during 5 seconds within short segments of the cord lumina (Fig. 1Q). Thus, over time, the melanoma cell cords appeared to become at least partially hollow for short distances.

When dissociated endothelial cells were embedded in thick matrix (either Matrigel or type I collagen), they also formed networks of cords via in vitro vasculogenesis (Fig. 1R). When everted rat aortic grafts (Nicosia et al, 1997) were embedded in thick matrix to simulate angiogenesis in vitro, endothelial cells also formed branching cords generating networks (Fig. 1S), similar to in vitro vasculogenic networks. Under identical matrix conditions, nonaggressive melanoma cells did not form cords but instead formed noncontiguous aggregates of fewer than 20 cells (Fig. 1T), regardless of plating density. Aggressive melanoma cells under identical matrix and cell density conditions did not form cords but instead formed looping patterns that outlined spheroidal nests of tumor cells (Fig. 1U) (Maniotis et al, 1999). In 2-week cultures, elongated tumor cells were embedded within the looping patterns (Fig. 1V). In early cultures, it was not possible to inject dyes into these patterns. However, in mature cultures of 2 weeks or longer, these looping patterns were capable of conducting Texas red dye that had been microinjected (Fig. 1W). Thus, depending on the age of the culture, the looping patterns appeared to be solid in some areas and variably hollow in others as reported previously (Maniotis et al, 1999).

In vivo, tumor cells do not grow on rigid, nondeformable or tethered surfaces. Therefore, tumor cells were embedded in floating collagen gels to test their behavior on deformable surfaces. Aggressive melanoma cells in 2-week cultures generated matrix-rich patterns: tumor cells were aligned along the patterns and were embedded in an amalgam of matrix (Fig. 1X), similar to their behavior in thick Matrigel (Fig. 1V). When collagen gels containing aggressive melanoma cells that had generated looping patterns were incubated with Texas red administered iontophoretically through a wide-caliber micropipette, the dye distributed passively along the patterns (Fig. 1Y), similar to 
Table 2. The Influence of Matrix Thickness on the Morphogenetic Potential of Endothelial Cells and Melanoma Cells

\begin{tabular}{|c|c|c|c|c|}
\hline \multirow[b]{2}{*}{ Culture designation } & \multicolumn{4}{|c|}{ Matrix conditions } \\
\hline & $\begin{array}{l}\text { In serum-soluble } \\
\text { matrix }\end{array}$ & $\begin{array}{l}\text { On matrix adsorbed } \\
\text { to rigid surface }\end{array}$ & On thin matrix & $\begin{array}{l}\text { Embedded in thick } \\
\text { matrix }\end{array}$ \\
\hline Endothelial cells & Small aggregates & $\begin{array}{l}\text { Cobblestone } \\
\text { monolayers }\end{array}$ & $\begin{array}{l}\text { Cord formation } \\
\text { (blocked by } \\
\text { TNP470) }\end{array}$ & Cord formation \\
\hline $\begin{array}{l}\text { Nonaggressive } \\
\text { melanoma cells }\end{array}$ & Small aggregates & Small aggregates & Small aggregates & Small aggregates \\
\hline $\begin{array}{l}\text { Aggressive } \\
\text { melanoma cells }\end{array}$ & Large aggregates & Large aggregates & $\begin{array}{r}\text { Cord formation } \\
\text { (not blocked } \\
\text { by TNP 470) }\end{array}$ & Looping patterns \\
\hline
\end{tabular}

Endothelial cell types tested: pulmonary, dermal, and brain microvascular cells, human umbilical vein endothelial cells, aortic endothelial cells, and endothelial cells derived from hemangioma; nonaggressive melanoma cells: 0CM-1A; aggressive melanoma cells: C918, M619, MUM-2B.

the distribution of dye in these patterns after direct microinjection (Fig. 1W).

\section{Interaction of Aggressive and Nonaggressive Melanoma Cells with Endothelial Cells In Vitro}

Having compared the in vitro behavior of melanoma cells with endothelial cells separately under the influence of varying matrix quantities and holding levels of growth factors constant, we allowed melanoma cells and endothelial cells to interact in vitro under varying matrix quantities to study tropisms using methods described by Levi-Montalcini et al (1968).

An endothelial cell colony was placed onto a lowdensity matrix that was patterned onto the substratum (Fig. 2, A1). Aggressive melanoma cells were added to an area of the coculture that did not contain any inscribed matrix. Aggressive melanoma cells aggregated into a tight mass over 24 hours (Fig. 2, A1 and A2), identical to their behavior at high seeding densities under the same conditions in isolation (Fig. $1 \mathrm{H}$ ). The endothelial cell colony, placed on thin inscribed matrix and separated by $0.5 \mathrm{~mm}$ from the melanoma cells, formed a network of cords as expected (Fig. 2, A2 and A3), identical to endothelial cell behavior in isolation (Fig. 1I). After 18 to 24 hours, the edge of the tumor aggregate flattened and made contact with matrix underlying the endothelial cells (Fig. 2, A4). Once in contact with this matrix, the aggressive melanoma cells formed either tumor cells cords or matrixrich patterns, depending on the matrix thickness. Although both the melanoma cell aggregate and the endothelial cell colony migrated in the dish as distinct spatially separated colonies, time-lapse photography consistently demonstrated that the endothelial cell cords arrived at the flattened edge of the aggressive tumor aggregates before cords of melanoma cells invaded the endothelial cell colony (Fig. 2, A5 and A6). These endothelial cell cords penetrated the edge of the melanoma cell aggregate consistently (Fig. 2, A6) and made contact with the tumor cell-generated matrix-rich patterns, but the endothelial cords did not appear to penetrate further along these patterns.

When aggressive melanoma cells and endothelial cells were both plated on thin matrix in coculture, both cell types formed cords (Fig. 2B) similar to both their behaviors in isolation (see Fig. 1, I, J, L, and M). When aggressive melanoma cells and endothelial cells were embedded within matrix, endothelial cells formed cords as in Figures $1 \mathrm{R}$ and $1 \mathrm{~S}$, whereas aggressive melanoma cells formed spheroidal nests surrounded by a patterned matrix-rich amalgam containing tumor cells (Fig. 2C). Nonaggressive melanoma cells failed to form patterns under identical conditions (Maniotis et al, 1999).

It was difficult to observe the interactions between endothelial cells and aggressive melanoma cells where both cell types were embedded within matrix. We therefore prelabeled endothelial cells with acetylated low-density lipoprotein (LDL) and seeded them onto mature cultures of nonaggressive nonpatternforming/melanoma cells and aggressive patternforming melanoma cells that were embedded in matrix. Prelabeled endothelial cells coexisted with nonaggressive nonpattern-forming melanoma cells for up to 5 days but did not form cords (Fig. 2, D and E). By contrast, an equal initial number of prelabeled endothelial cells preferentially localized to patterns formed by aggressive melanoma cells for 24 hours (Fig. 2, F and G) and formed short cords (Fig. 2, F to J). However, after only 24 to 48 hours, the number of prelabeled endothelial cells diminished compared with equal numbers of endothelial cells incubated with nonaggressive melanoma cells, until very few labeled endothelial cells were detected either along the patterns or elsewhere and short endothelial cell cords along patterns were no longer observed.

To further test the direct interaction between endothelial cells and melanoma cells, we compared the ability of endothelial cells to penetrate nonaggressive, nonpattern forming melanoma cells and aggressive pattern-forming melanoma cells using combined fluorescence and interference reflection microscopy by detecting physical contact between the endothelial cell and a surface within 30 to $40 \mathrm{~nm}$ (Fig. 2, $\mathrm{K}$ to $\mathrm{U}$ ). When prelabeled microvascular endothelial cells were seeded onto nonaggressive nonpattern-forming melanoma cells on matrix, endothelial cells penetrated the tumor cell cultures. The penetration of these cells 

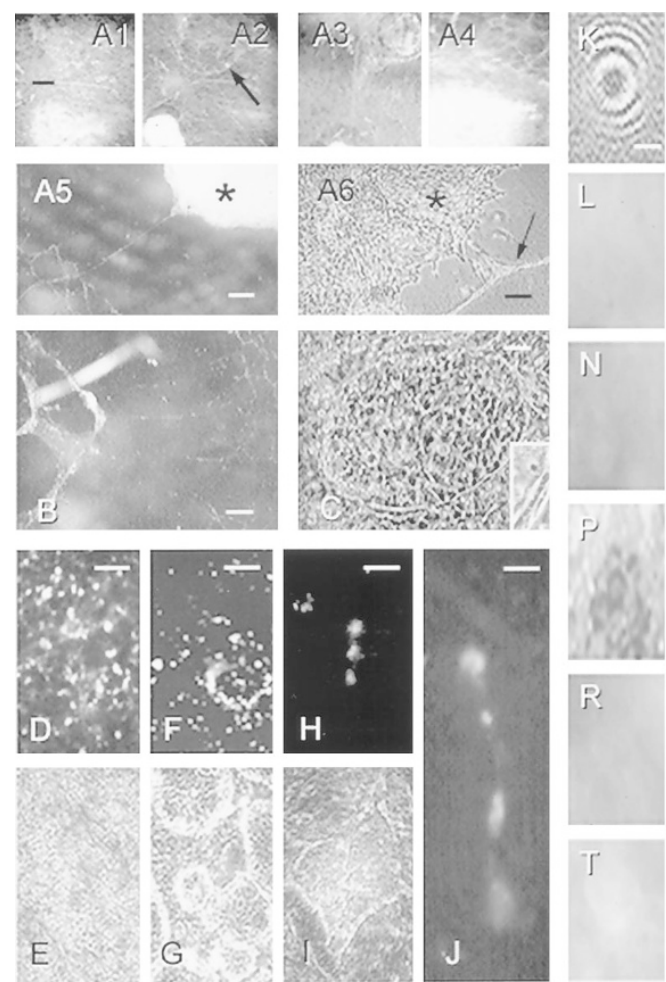

Figure 2.

Melanoma cell-endothelial cell cocultures. A1 to A6, Interactions between aggressive melanoma cells and MECs spatially separated by $0.5 \mu \mathrm{m}$. A1, One hour after seeding: bar is positioned halfway between colonies, endothelial colony at top and melanoma colony below bar; A2, after 24 hours, arrow points to edge of colony; $\mathrm{A} 3$, after 30 hours. A4, Extensive contact between endothelial cell colony and aggressive melanoma. A5, Early tropism of endothelial cells toward aggressive melanoma aggregate (asterisk). A6, Cords of endothelial-cells (arrow) making contact with aggressive melanoma colony (asterisk). B, Endothelial cells (thin cords on right) and aggressive melanoma cells (thicker cords on left) both seeded on thin matrix. C, Spheroidal nest of melanoma cells surrounded by a matrix-rich amalgam that contained tumor cells (inset); endothelial cells in this coculture cannot be identified without labeling. D to J, Prelabeling of MECs with acetylated LDL and their interaction with nonaggressive and aggressive melanoma cells on thick matrices. D, Fluorescence and E phase contrast images of prelabeled MECs incubated with pre-established culture of nonaggressive melanoma cells; $\mathrm{F}$, same initial number of prelabeled MECs incubated with aggressive primary melanoma; $G$, phase of $\mathrm{F} ; \mathrm{H}$, same number of prelabeled MECs incubated with prelabeled aggressive metastatic melanoma; I, phase of $\mathrm{H}$; $\mathrm{J}$, the longest cord of MECS observed along matrix. $\mathrm{K}$ to $\mathrm{V}$, Labeled endothelial cells with nonaggressive and aggressive cultures of melanoma cells on thick matrix: L, N, P, R, and Tare taken by interference-reflection (a technique that shows a dark signal when contact is made and a white signal or no signal in the absence of direct contact); $\mathrm{M}, \mathrm{O}, \mathrm{Q}, \mathrm{S}$, and $\mathrm{U}$ are corresponding fluorescence images. K, Calibration bead. L-M, N-O, P-Q, Endothelial cells at various depths in culture of nonaggressive OCM-1A melanoma cells: superficial penetration in L-M, intermediate depth in $\mathrm{N}-\mathrm{O}$, and complete penetration in $\mathrm{P}-\mathrm{Q}$. Adhesion is noted in $\mathrm{P}-\mathrm{Q}$ by the dark interference reflection signal in $\mathrm{P}$ (compare with the calibration bead in $\mathrm{K}$ ) and the elongated or spreading morphology of the corresponding endothelial cell, characteristic of adhesion, as detected by fluorescence in Q. N-0, Endothelial cell at an intermediate depth. R-U, Endothelial cells on a culture of aggressive pattern forming MUM-2B melanoma cells. There is no interference reflection signal (R-T), and the endothelial cells remain round (S-U) instead of elongated or spreading: both of these observations indicate that these endothelial cells are nonadherent. Bar in series $A 1$ to $A 4=100$ $\mu \mathrm{m}$; bars in $A 5$ and $B=20 \mu \mathrm{m}$; bar in $A 6=20 \mu \mathrm{m}$; bar in $\mathrm{C}=20 \mu \mathrm{m}$; bars in $D$ to I $=75 \mu \mathrm{m}$; bar in $\mathrm{J}=5 \mu \mathrm{m}$; bar in $\mathrm{K}=0.5 \mu \mathrm{m}$; bar in $\mathrm{L}$ to $\mathrm{U}=10 \mu \mathrm{m}$.

through the cultures was documented over 24 hours through various depths within the culture (Fig. 2, L to O) until the endothelial cells completely penetrated the cultures, established interference reflection-visible adhesions beneath the nonaggressive melanoma cells
(Fig. 2P), and assumed the elongated morphology characteristic of spreading that accompanies adhesion (Fig. 2Q). By contrast, prelabeled endothelial cells placed on aggressive pattern-forming melanoma cells on matrix did not establish interference reflectionvisible adhesions (Fig. 2, R and $\mathrm{T}$ ) and remained round (Fig. 2, S and U). When followed in culture for 48 hours, these nonadherent rounded cells floated and lysed in agreement with the requirement of adhesion for endothelial cell survival (Chen et al, 1997).

Having observed the differential ability of prelabeled microvascular endothelial cells to penetrate and form cords on matrix-containing cultures of nonagressive and aggressive melanoma cells, we tested the ability of melanoma cells to penetrate a single layer of endothelium. Nonaggressive melanoma cells did not penetrate through the endothelial monolayer during 2 weeks of observation (Fig. 3A), confirming the ability of endothelial cells to survive in the presence of nonag-

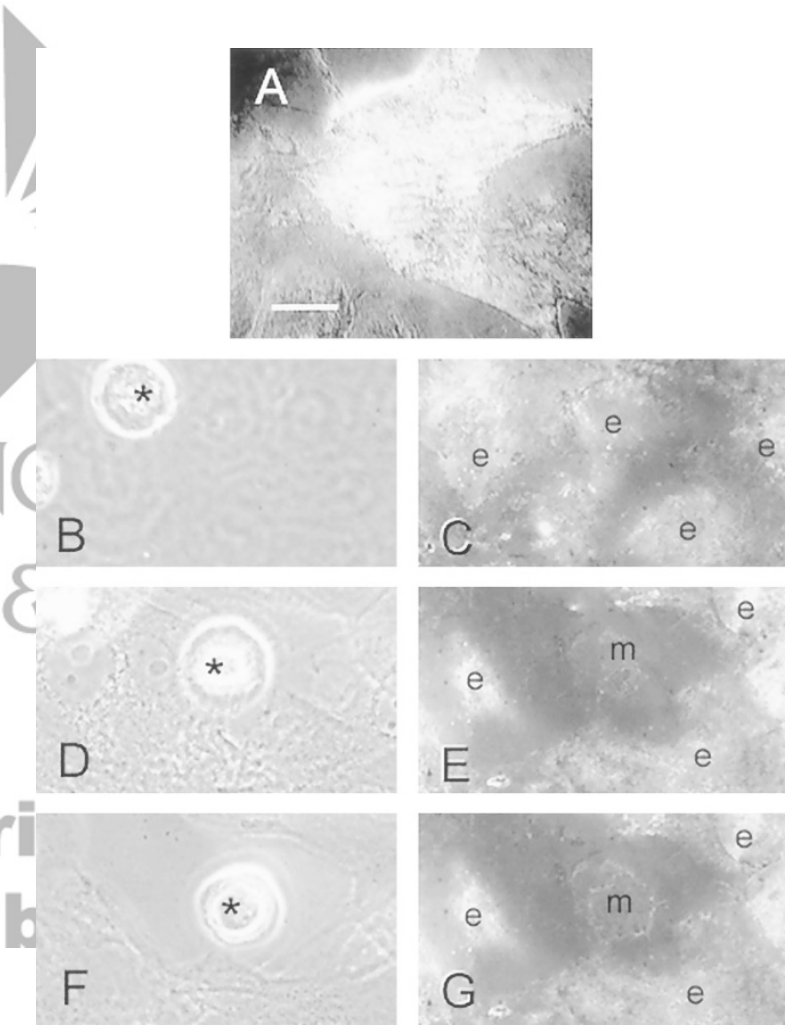

Figure 3.

Invasion of melanoma cells through endothelial monolayers. A, Interference reflection micrograph of a group of nonaggressive melanoma cells (white) cocultured on an endothelial monolayer for 2 weeks. B to G, Invasion of aggressive melanoma cells on endothelial monolayer. B, Phase image of one aggressive melanoma cell (asterisk) placed on endothelial monolayer at time zero. C, Same preparation as B, photographed by interference reflection. The tumor cell is not visible by interference reflection because it has not made contact $(e=$ endothelial cell). D, Phase image of same melanoma cell (asterisk) depicted in B after making contact with and penetrating endothelium after 60 minutes. E, Same preparation as in D, photographed by interference reflection. The melanoma cell $(m)$ has made interference reflection positive contact and is now visible. Note the separation between melanoma cell and neighboring endothelium. The endothelial cells in $\mathrm{E}$ appear smaller than those in $\mathrm{C}$ because of a partial loss of adhesion. $\mathrm{F}$, Phase image of same melanoma cell (asterisk) as in B and D after 80 minutes. Note further disruption of the endothelial monolayer adjacent to the melanoma cell. G. Same preparation as $F$, photographed with interference reflection. Bar in $A$ to $G=10 \mu \mathrm{m}$. 
gressive melanoma cells and their inability to form cords in the presence of nonaggressive tumor cells. By contrast, when an aggressive melanoma cell was placed on endothelial monolayers, the tumor cell penetrated the monolayer in 61 minutes (Fig. 3, B to G), and endothelial cell lysis was observed after $61 \mathrm{~min}$ utes of contact with an aggressive melanoma cell.

\section{Human Primary and Metastatic Melanoma}

As shown above, aggressive melanoma cells are capable of generating two types of potential fluidcontaining structures in vitro depending on local matrix thickness: tubes (Fig. 1, I to Q) and looping patterns containing matrix and tumor cells that encircle spheroidal packets of tumor cells (Fig. 1, V and X). In a previous report, Folberg et al (2000) did not distinguish between these two types of tumor cellgenerated structures and illustrated only the ultrastructure of a tube containing red blood cells. In the current study, therefore, looping patterns in tissue section that correspond morphologically to looping patterns generated by aggressive tumor cells in vitro were detected in human tissue samples of primary and metastatic melanoma and studied by light and transmission electron microscopy.

Tumor tissue was prepared for transmission electron microscopy immediately after excision by immersion fixation in glutaraldehyde and tissue microdissected to identify areas that contained looping patterns that are identifiable easily in formalin-fixed tissue with the PAS stain. Figure 4A shows a tissue section of a primary uveal melanoma after formalin fixation stained by PAS without hematoxylin counterstain containing back-to-back loops. Figure 4, B to F, is representative of the ultrastructure of the looping patterns in glutaraldehyde-fixed tissue.

Figure 4B illustrates an arcing segment of a loop. Tumor cells are present on either side of the thin structure that arcs from the lower left of Figure 4B to the upper right of the micrograph. The thin PASpositive looping material that appears to be solid by light microscopy (Fig. 4A) is ultrastructurally a sandwich of electron-dense material of irregular thickness on either side of a central layer of melanoma cells (Fig. $4 \mathrm{~B}$, inset). The composition of the loop therefore is strikingly similar to the appearance of patterns formed by aggressive melanoma cells in vitro only under thick matrix conditions (Fig. 1, $\mathrm{U}$ to $\mathrm{Y}$ ).

The patterns, however, are not entirely solid. In some areas, blood cells were detected between the melanoma cells that contributed to the central layer of the looping patterns (Fig. 4C). Thin homogeneous material of moderate electron density was detected adjacent to the red blood cells (Fig. 4E), and this material extended in thin ribbons between the melanoma cells that comprised the central cores of the patterns (Fig. 4E). This material lacked the ultrastructural characteristics of fibrin and was not detected outside of the patterns. The ultrastructural composition of the thin loops that encircle the spheroidal tumor cell packets was clearly different from endothelial
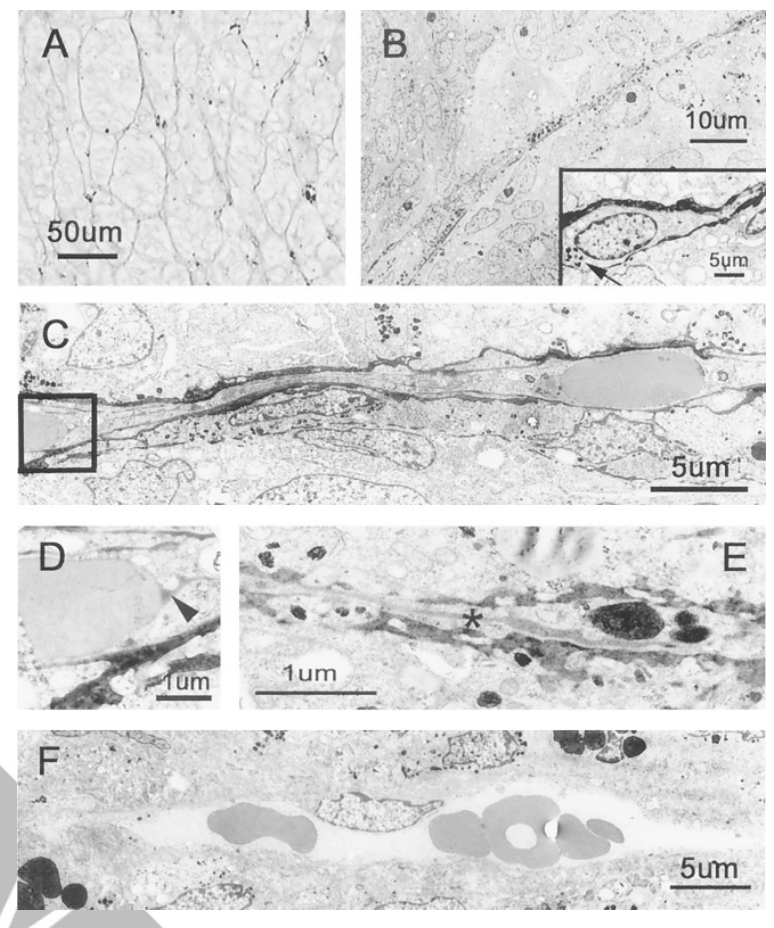

Figure 4.

Human primary uveal melanoma. A, Primary uveal melanoma stained with PAS without hematoxylin counterstaining. Note back-to-back loops. B, Transmission electron micrograph of a segment of a PAS-positive loop from tissue immersion fixed in glutaraldehyde. The segment of the loop arcs from the lower left to the upper right of the micrograph. Electron dense material is present on either side of a central layer of melanoma cells (inset at higher magnification shows tumor cell with melanosomes sandwiched between two layers of electron dense material). C, Primary human uveal melanoma tissue immersion fixed in glutaraldehyde. In this segment of a loop, red blood cells are identified adjacent to the tumor cells in the central layer flanked by electron-dense material. The area within the box is illustrated at higher magnification in D. D, Note the presence of homogeneous material of moderate electron density adjacent to the red blood cells (arrow), which extends between the tumor cells entrapped between the two layers of electron-dense material. $\mathrm{E}$, The homogeneous material identified next to the red blood cell in $\mathrm{E}$ extends between melanoma cells (asterisk). This material does not have the characteristic appearance of fibrin. F, Primary human uveal melanoma tissue immersion fixed in glutaraldehyde. Blood vessel lined by endothelium. Com-

\section{pare with $\mathrm{C}$.}

cell-lined blood vessels seen in the same tissue samples (Fig. 4F).

Because tracer material was detected within extravascular patterned loops in animal models after intravenous injection (Potgens et al, 1996; Shirakawa et al, 2002) and because scattered red blood cells were observed within these patterns (Fig. 4F), we suspected that plasma might be present in the patterns as well. We used fibrinogen as a surrogate tissue marker for the presence of plasma. Sections adjacent to those containing PAS-positive looping patterns were double-stained for fibrinogen and laminin (Fig. 5, $A$ and B). Laminin-positive patterns connected to blood vessels, consistent with the previous demonstrations of connections between blood vessels and looping PAS-positive patterns (Folberg et al, 1997, 2000). Fibrinogen was detected just outside the walls of blood vessels and within the extravascular lamininpositive loops connected to the vessels and encircling packets of tumor cells. Fibrinogen was not detected 

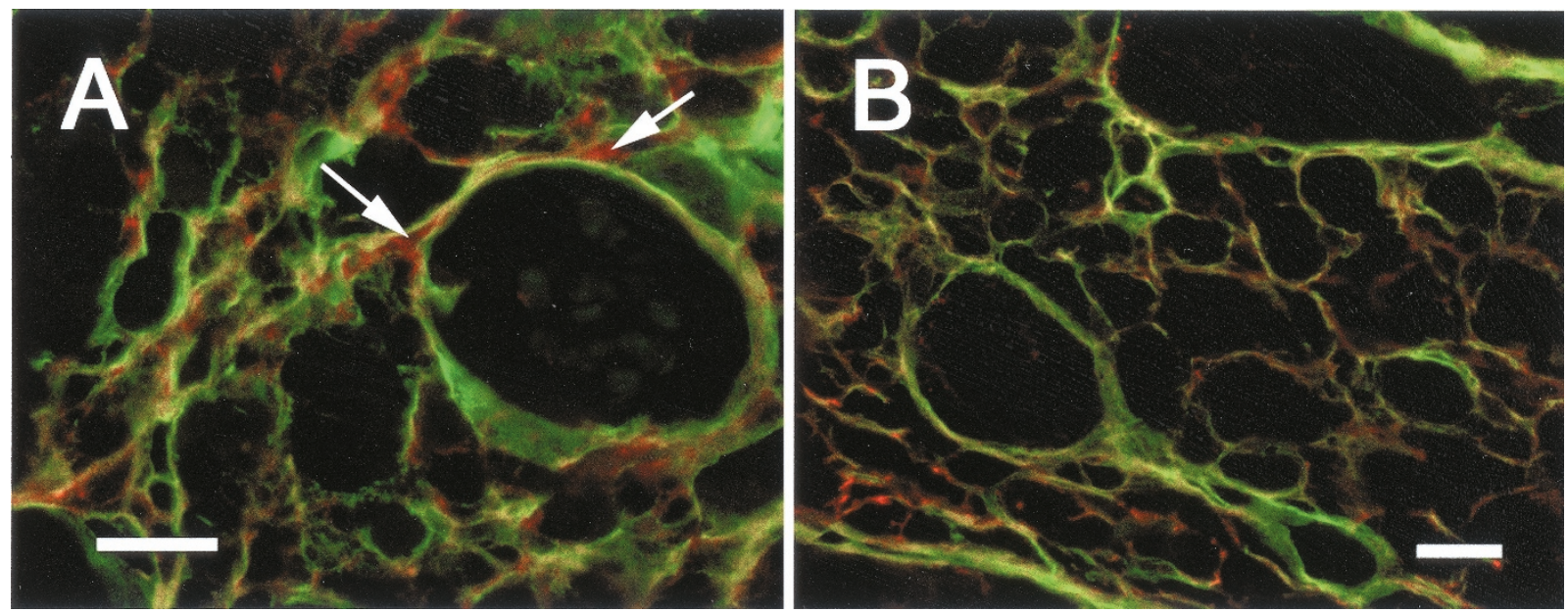

Figure 5.

Human primary uveal melanoma. A and B, Double label for laminin (green) and fibrinogen (red). In A, note the presence of fibrinogen just outside the wall of the blood vessel (arrows). Elsewhere, fibrinogen colocalizes to laminin-positive loops and is not diffusely distributed throughout the tissue. In B, a scanning magnification, note the colocalization of fibrinogen (red) to laminin-positive loops (green). Bar $=20 \mu \mathrm{m}$.

within tumor cells or in a diffuse distribution throughout the tumor sample.

\section{Discussion}

\section{Matrix and Morphogenesis of Endothelial and Melanoma Cells}

In this study, we compared the behavior of nonaggressive and aggressive melanoma cells with endothelial cell behavior in conditions promoting or suppressing endothelial cell growth and differentiation that have been well characterized by others (Folkman and Moscona, 1978; Ingber and Folkman, 1989; Maniotis et al, 1997; Vernon et al, 1992). Aggressive melanoma cells formed cords that were similar to the appearance of endothelial cell cords only on thin matrix. These tumor cell-generated cords were, at first, solid and filled with tumor cells but later became partially hollow and capable of containing fluid for short distances.

Aside from the specific culture condition of thin matrix, the behavior of tumor cells was far different from endothelial cells in at least three respects. First, in the condition of soluble matrix without a substratum that we used to promote spheroid self-assembly, aggressive melanoma cells made large aggregates (approaching the size of human primary tumors), whereas neither nonaggressive melanoma cells nor endothelial cells formed large aggregates. Thus, it appears that the self-aggregation (self-assembly) properties of aggressive melanoma cells are superior to those exhibited by either endothelial cells or nonaggressive melanoma cells. However, these aggregates become necrotic centrally, and matrix is not generated in these aggregates. Second, in the presence of matrix proteins adsorbed to a single rigid surface, neither nonaggressive melanoma cells nor aggressive melanoma cells formed cobblestone monolayers (analogous to the luminal surface of blood vessels) as observed with a variety of endothelial cells.
Thus, although aggressive melanoma cells may form tubes under well-defined matrix conditions, it is clear that these tubes are not blood vessels.

Finally, when embedded in matrix, endothelial cells formed either vasculogenic or angiogenic cords as expected, but nonaggressive melanoma cells formed very small aggregates and aggressive melanoma cells formed patterns encircling spheroidal packets of tumor cells: the patterns themselves contained matrix and were filled in part with tumor cells. These patterns were solid in earlier cultures and were variably hollow in later cultures, permitting them to conduct fluid for short distances after microinjection as described previously (Maniotis et al, 1999) and after passive contact with fluid as shown above in embedded cultures. The mechanisms by which fluid is contained within these patterns without leakage are not clear and are under further investigation.

= Thus, depending upon matrix conditions, aggressive melanoma cells may make either tubes or patterns that are capable of containing and conducting fluid. The generation by aggressive tumor cells of pathways capable of transporting fluid was termed "vasculogenic mimicry": the word "vasculogenic" was selected to indicate the generation of the pathway de novo instead of from pre-existing vessels to distinguish the generation of these pathways from preexisting vessels, and the word "mimicry" was used because tumor cell pathways for transporting fluid in tissues were clearly not blood vessels. Thus, the current study demonstrates that there are at least two forms of vasculogenic mimicry-tubular and patterned-that depend on at least two factors: the presence within the tumor of an aggressive, genetically deregulated tumor cell phenotype and local matrix conditions. Neither appropriate matrix conditions nor the aggressive tumor cell phenotype alone is sufficient to generate either tubes or patterns: nonaggressive cells generate neither tubes nor patterns, and 
aggressive cells generate either tubes or patterns depending upon matrix conditions.

\section{Matrix Control of Endothelial Cell-Tumor Cell Interactions}

When endothelial cell colonies were cocultured with aggressive melanoma cells on thin matrix, endothelial cell cords contacted the aggressive tumor cell colony but did not penetrate into the colony. This suggested that aggressive tumor cells might not be permissive of endothelial cell penetration or long-term survival, although the patterned matrix generated by aggressive tumor cells may permit limited survival. After seeding prelabeled endothelial cells onto aggressive melanoma cells embedded in matrix that had been allowed to form matrix-rich patterns, we observed only limited endothelial cell survival and cord formation along the matrix patterns (up to 48 hours) but no survival where patterns were absent. The round shape of endothelial cells on aggressive melanoma cells where matrix is absent is consistent with known mechanisms of adhesion-dependent geometrical control of endothelial cell survival and death (Chen et al, 1997).

By contrast, endothelial cells survived in contact with nonaggressive nonpattern-forming melanoma cell cultures for up to 5 days but did not form cords. Additional studies in which endothelial cells were permitted to attempt to penetrate melanoma cell monolayers, and melanoma cells were permitted to penetrate endothelial cell monolayers again, confirmed a relative coexistence of endothelial cells with nonaggressive melanoma cells for 2 weeks and lysis of endothelial cells on direct contact with aggressive melanoma cells in 80 minutes. In considering the limited survival of endothelial cells along/matrix-rich patterns, it is worth noting that the patterns themselves are composed of matrix and aggressive tumor cells: that endothelial cells survive along these patterns for a limited time may be a function of tumor cell density and direct tumor cell contact because endothelial cells are lysed upon contact where the patterns are absent.

\section{The Potential Role of Matrix-Modulated Tumor Cell Morphogenesis in Perfusion}

Histologic evidence of tubes lined by tumor cells have been reported in melanoma (Baron et al, 2000; Hammersen et al, 1985; Konerding et al, 1989a, 1989b; Prause and Jensen, 1980; Timar and Toth, 2000), ovarian carcinoma (Sood et al, 2001), and inflammatory breast cancer (Shirakawa et al, 2001, 2002). Although it has been suggested that tumor cells actively participate in the generation of these tumor cell-lined tubes (Baron et al, 2000; Shirakawa et al, 2001, 2002; Sood et al, 2001), it is also possible that some tumor cell-lined tubes and sinusoids are fashioned by streams of blood dissecting through tumor (Nasu et al, 1999) or that they represent blood vessels in which the entire endothelial cell lining has been replaced by tumor cells (perhaps an end-stage of mosaicism; Chang et al, 2000). The contribution of tumor cell-lined tubes to a functional microcirculation is unclear; however, Folkman (2001) has suggested that tumor cells in the lining of blood-conducting channels may facilitate metastasis.

PAS-positive looping patterns enclosing spheroidal packets of tumor cells have been identified in uveal (Folberg et al, 1993) and cutaneous melanoma (Thies et al, 2001; Warso et al, 2001), and the presence of these patterns is very strongly associated with death from metastatic melanoma. It has been shown that laminin is a component of the looping patterns in animal models of cutaneous melanoma (Potgens et al, 1996), in human cutaneous melanoma (Thies et al, 2001), in ovarian carcinoma (Sood et al, 2001), and in inflammatory breast cancer (Shirakawa et al, 2001). Seftor et al (2001) recently showed that aggressive cutaneous and uveal melanoma cells deposit laminin in vitro in looping patterns and that melanoma cells used the patterned laminin loops as scaffold along which they migrated.

Several lines of evidence from established animal models indeed suggest that plasma is conducted through laminin-positive looping patterns. Potgens et al (1996) detected looping patterns in xenografts of cutaneous melanoma that were morphologically identical to those seen in histologic sections of uveal and cutaneous melanoma: intravenously administered tracer distributed in blood vessels and in extravascular thin loops that stained positive for heparan sulfate proteoglycan and laminin but did not contain endothelial cells. Curiously, tracer material did not leak from the loops into the surrounding tissue compartment. Shirakawa et al (2001) demonstrated that the WIBC-9 cell line derived from a patient with inflammatory breast/cancer not only formed tubes as mentioned above but also loops similar to those described in human melanomas and in the model reported by Potgens et al (1995). More recently, Shirakawa et al (2002) demonstrated a physiologic connection between the systemic circulation and loops by means of time-coursed dynamic micromagnetic resonance angiography analysis in their animal model: the contrast agent colocalized to loops in the xenograft model.

The localization of intravenous tracer material to looping patterns of laminin in animal models is consistent with three observations made in the current study: (1) looping patterns formed by aggressive melanoma cells are capable of containing and distributing fluid in vitro; (2) ultrastructurally, the patterns are not entirely solid and contain red blood cells; and (3) fibrinogen colocalized to laminin-positive looping patterns in human tumor samples. Although fibrin has been demonstrated previously in human tumor samples in looping patterns, originating presumably from leaky blood vessels, the mechanism responsible for the patterning of fibrin into back-to-back loops (Nagy et al, 1989) has not been explored previously. It is well established that tumor vessels are leaky and that factors such as vasoproliferative factor/vascular endothelial growth factor may contribute to this increased tumor vessel permeability (Nagy et al, 1989). In the 
current study, we demonstrated that aggressive pattern-forming melanoma cells damage endothelial cells, thus providing yet another mechanism by which tumor vessels may become leaky. Thus, plasma and red blood cells leaking from tumor vessels may be directed along the pathway of the laminin-positive patterns rather than diffusing randomly throughout the tissue.

It is well known that plasma leaking from incompetent tumor vessels may be the source of extravascular fibrin which, in turn, plays a pivotal role in the development of a tumor stroma (Nagy et al, 1989). The tumor cell compartment of uveal melanoma, however, is remarkable for a general lack of a fibrous stroma within the tumor cell compartment in the absence of radiation treatment or necrosis (Folberg et al, 2000). Despite colocalization of fibrinogen to laminin looping patterns and the presence of red blood cells within these patterns, ultrastructural examination of these patterns disclosed no evidence of deposits characteristic of the ultrastructurally distinctive appearance of fibrin. Indeed, it is possible that the formation of fibrin in patterns formed by tumor cells is blocked by factors produced by the aggressive tumor cells. It has been shown recently that tissue factor pathway inhibitor (TFPI) 1 and 2 are expressed by the aggressive pattern-forming MUM-2B melanoma cell line used in this study by 18- and 31-fold, respectively, compared with the nonaggressive MUM-2C melanoma cell line (Seftor et al, 2002). TFPI-1 a major inhibitor of the serine protease activity of the tissue factor-VIla coagulation complex (Broze, 1995) and TFPI-2 is a serine protease inhibitor similar to TFPI-1. Endothelial cellderived tissue factor pathway inhibitor is thought to regulate the tissue factor-VIla complex-a critical initiator of the coagulation pathways (Broze, 1995).

The presence of looping patterns in histologic sections of primary tumors has been shown repeatedly (Makitie et al, 1999a; McLean et al, 1997; Sakamoto et al, 1996; Seregard et al, 1998) to have an exceptionally strong association with death from metastatic melanoma, and these patterns are found in metastatic melanomas regardless of the site of metastasis (Rummelt et al, 1998). Moreover, it is unusual for patients to die of metastatic uveal melanoma if the primary tumor does not contain networks of matrix-rich patterns (Folberg et al, 1993). Therefore, the presence of these patterns, capable of being generated by aggressive tumor cells without participation by endothelial cells or fibroblasts, may be a maker of a "malignant switch" in this tumor system.

The establishment of looping patterns containing matrix and tumor cells by aggressive melanoma cells may contribute to metastasis by several mechanisms. Seftor et al (2001) have shown that melanoma cells in vitro not only deposit laminin in looping patterns but that melanoma cells use these patterns as a scaffold for migration. The flow of plasma through looping matrix patterns, as shown in animal models and suggested in human tissue by colocalization of red blood cells and fibrinogen to these patterns, provides a pathway by which aggressive tumor cells that gener- ate and populate these patterns can gain access to the systemic circulation. The expression of TFPI-1 and TFPI-2 by the aggressive pattern-forming melanoma cells may not only play a critical role in preventing coagulation within these patterns but may facilitate tumor cell adhesion and migration (Fischer et al, 1999) and may potentiate invasion mediated by hepatocyte growth factor (Neaud et al, 2000), which has been shown previously to enhance invasive properties of aggressive melanoma cells (Hendrix et al, 1998).

The microcirculation of aggressive uveal melanomas may be quite complex, consisting of incorporated vessels (Thompson et al, 1987), co-opted vessels (Holash et al, 1999), mosaic vessels (Chang et al, 2000), angiogenic vessels (Folkman, 1996), and looping matrix-rich patterns that are capable of conducting blood cells and plasma. The establishment of nonvascular tumor cell-generated conduits for blood transport may exist in concert with other forms of blood transport in these tumors and may facilitate metastasis.

\section{Materials and Methods}

\section{Cell Culture}

Cell lines were derived from normal choroidal melanocytes (UMEL-1), primary choroidal melanoma (OCM1A, C918, and M619), and from a focus of metastatic uveal melanoma (MUM 2B) to the liver as described previously (Kan-Mitchell et al, 1989; Maniotis et al, 1999). Melanoma cells were plated in DMEM (BioWhittaker, Inc., Walkersville, Maryland), and supplemented with $10 \%$ fetal bovine serum (Fisher, Ontario, Canada) without the addition of exogenous extracellular matrix molecules. Endothelial cells derived from pulmonary (Clonetics, San Diego, California), brain, and dermal microvasculature (HMEC-1), human umbilical vein endothelial cells, and embryonic chick endothelial cells were maintained in DMEM and $20 \%$ fetal bovine serum supplemented with basic fibroblast growth factor. No antibacterial or antifungal drugs were used in the maintenance of cell lines or in experiments, because their chronic use has been shown by us (Strohman et al, 1990) and others to interfere with the differentiative potential of other primary cell types. For production of mass cultures for aggregates, 500-ml shaker flasks were prepared with a precoating of serum, and cells were added with DMEM and serum. All cell cultures were determined to be free of mycoplasma contamination using the GenProbe rapid detection system (Fisher, Itasca, Illinois).

\section{Invasion Assay}

Tumor cells $\left(10^{5}\right)$ were seeded into the upper wells of the MICS chamber (Hendrix et al, 1987) onto collagen/ laminin/gelatin-coated (Sigma, St. Louis, Missouri) polycarbonate membranes containing $10-\mu \mathrm{m}$ pores (Osmonics, Livermore, California) in DMEM containing $1 \times \mathrm{MITO}+$ (Collaborative Biomedical, Bedford, Massachusetts). After 24 hours of incubation at $37^{\circ} \mathrm{C}$, the cells that invaded each membrane were collected, 
stained, and counted (Hendrix et al, 1996). Percent invasion was corrected for proliferation and calculated as follows:

$$
\frac{\text { Total number of invading cells }}{\text { Total number of cells seeded }} \times 100
$$

\section{Tumor Cell Aggregates}

To construct tumor cell aggregates between 5 and 12 $\mathrm{mm}$ in diameter in the absence of blood vessels or heightened $\mathrm{O}_{2}$, methods using agarose and agar were adapted from Frankel et al (1997). Briefly, DNA grade agarose (Lot 162-0134; BioRad, Richmond, California) or agar (Lot 12945-036; Gibco, Burlington, Massachusetts) was heated to $60^{\circ} \mathrm{C}$, and after liquefaction, the melted agar or agarose was poured into $100-\mathrm{ml}$ beakers that were placed on slanted shelves (Vernon et al, 1995) such that when the liquefied agarose or agar cooled, it would solidify into slanted wells to increase cell collisions between suspended cells and thereby increase their association when placed into rotary shakers inside $37^{\circ} \mathrm{C}, 5 \% \mathrm{CO}_{2}$ incubators.

\section{Matrix-Containing Cultures}

Two hundred fifty microliters of Matrigel or type I collagen (Collaborative Biomedical) was dropped onto glass coverslips and allowed to polymerize for 1 hour at $37^{\circ} \mathrm{C}$. Tumor cell lines or endothelial cells were then seeded on top of the gels at different densities depending on the assay.

\section{In Vitro Vasculogenesis/Angiogenesis Assays}

To compare the ability of tumor cells and human microvascular cells in isolation and in coculture to induce the vasculogenic formation of cords under matrix conditions permissive for cord or endothelial tube formation (Ingber and Folkman, 1989; Vernon et al, 1995), varying densities of adsorbed matrix with serum present were precoated onto a coverslip placed in 6-well plates (Falcon, Applied Scientific, San Francisco, California). Parallel cell cords in tumor or endothelial monocultures were induced to form with aggressive human melanoma cells and human microvascular cells, aortic endothelial cells, brain microvascular cells, endothelial cells derived from hemangioma, and fibroblastic cells negative for acetylated LDL and Ulex by positioning the adsorbed matrix, before it dried onto culture plates, with "microbrushes" that we fashioned out of glass needles on a microforge. Under these conditions, cords of cells exhibiting a lumen were induced within 48 hours only in these areas where matrix was "painted" on the coverslip: cells immediately adjacent to the painted-on matrix exhibited different morphology and never were observed to form cords. To assay angiogenesis in vitro, freshly cut rat aortic rings were used to generate microvascular outgrowths in serum-free collagen gel culture according to the methods of Nicosia (Levine and Nishiyama, 1996) with no modifi- cations. For human angiogenesis assays, fragments of human placental blood vessel or aorta were embedded in a fibrin gel in 35-mm Falcon tissue culture dishes and monitored for formation of networks of microvessels during a period of 7 to 21 days in culture.

\section{Conditioned Media Experiments}

For conditioned media experiments, media were collected, refrigerated, and passaged through a $0.2-\mu \mathrm{m}$ filter before being placed on the appropriate cells or cultures. Addition of nonaggressive or aggressive tumor-conditioned media did not interfere with endothelial growth or behavior (cell growth, activated motility, or cord formation) when matrix was present, nor did soluble factors (basic fibroblast growth factor, transforming growth factor- $\beta$, vascular endothelial growth factor, platelet-derived growth factor) induce cord or tube formation if matrix molecules were absent. To separate cords of cells in coculture formed by endothelial cells versus tumor cells, TNP-470 (a gift from Dr. Krysztoff Bojanowski, Sunny Biodiversity, Oakland, California, and Dr. Donald Ingber, Harvard Medical School, Boston, Massachusetts) was applied at concentrations previously established to completely block endothelial cord formation (Ingber et al, 1990; Kusaka et al, 1994).

\section{Microscopy of Live Cells and Tissues}

For live cell phase and fluorescence microscopy, we have modified a compound Leica microscope with on line video cameras possessing an entire range of high numerical aperture and diaphragm objectives, a 100W cmercury light soürce, a Sony intensified camera coupled to a AVID image intensifier (Sony Electronics, Park Ridge, New York), a Bioptechs (Bioptechs, Bannockburn, Illinois) objective heater, and still cameras. For high-resolution detection of live cell interactions between endothelial cells and tumor cells with this system, cells labeled with various markers (acetylated LDL-molecular probes, bisBenzimide; Sigma) were extensively washed and then seeded onto other cultures (either coated with matrix or uncoated). Longterm time-lapse videomicroscopy was performed on the Leica DM IRB inverted platform (Leica, Solms, Germany). For some of the long-term observation experiments, the Bioptechs Environmental Chamber System was used to maintain living cells in an environment where they may be microscopically observed and manipulated while being recorded in normal time or with time-lapse using $\times 20, \times 40, \times 63$, and $\times 100$ objectives for light, phase, differential interference contrast, or fluorescence microscopy. The system was also equipped with a 100W Atto-Arc lamp (Atto Bioscience, Rockville, Maryland) and complete filter sets for rhodamine, fluorescein, 4,6-diamidino-2phenylindole, and interference reflection microscopy; and each lamp has been equipped with a Uniblitz (Uniblitz, Rochester, New York) shutter and controller coupled to video recorders to facilitate time-lapse fluorescence microscopy of live cells by reducing the 
amount of transmitted light to millisecond time-frames of actual light exposure. Also, each system is coupled to a high resolution Sony color camera to further reduce the amount of light needed to capture highresolution but low-speed images. Time-lapse sequences were recorded on a Panasonic TL time-lapse video recorder (Panasonic, Osaka, Japan) and with a MacIntosh G4 (Apple Computer, Cupertino, California) equipped with $\mathrm{NIH}$ image.

\section{In Vitro Perfusion Studies}

Two methods were used to directly visualize perfusion of patterns generated by aggressive melanoma cell lines. Microcapillary pipettes (Narshige Scientific Instruments, Tokyo, Japan) were back-filled with buffered Texas red. The microneedle tip was then inserted by direct observation into a looping pattern, and fluid was injected under pressure at a rate of $30 \mu \mathrm{dyn} /$ second. Alternatively, for passive diffusion studies, a large bore micropipette $(2-4 \mu \mathrm{m})$ was placed near looping patterns, and fluid from the pipettes was administered iontophoretically.

\section{Histology and Histochemistry}

To highlight the matrix-rich networks surrounding spheroids of uveal melanoma cells, tissues were stained with PAS, omitting hematoxylin counterstaining to reduce visual noise, and imaged by black and white photography with a green filter (or the selection of the green channel for digital photography) to further highlight the PAS-positive patterns (Folberg et al, 1993). Failure to eliminate hematoxylin counterstaining with the PAS-stain has resulted in a $50 \%$ reduction in the histologic detection of matrix-rich patterns (McLean et al, 1997).

\section{Immunohistochemistry}

Slides adjacent to those containing PAS-positive loops were deparaffinized in xylene and rehydrated through a decreasing ethanol gradient. The slides were then rinsed in distilled water for 10 minutes, followed by antigen unmasking. Slides were then rinsed in PBS for 5 minutes. For double-labeling laminin and fibrinogen, slides were incubated with monoclonal anti-laminin antibody (Sigma L8271, clone Lam 89) at a dilution titer of 1:200 for 30 minutes at room temperature. Slides were then rinsed in protein blocking solution (DAKO, Carpinteria, California) for 10 minutes followed by detection with Alexa Fluor 488 goat anti-mouse IgG (Molecular Probes, Eugene, Oregon) for 30 minutes at a dilution of 1:400. Slides were then placed in double-stain blocking solution (DAKO) for 5 minutes, followed by incubation in rabbit antihuman fibrinogen antibody (DAKO; Lot 097602) at a dilution titer of 1:10,000. Antibody binding was detected with Alexa Fluor 594 (Molecular Probes A11012) for 30 minutes at a dilution titer of 1:400. Slides were rinsed in buffer and then mounted in Faramount Aqueous Mounting Medium (DAKO).

For all staining procedures, secondary antibody was omitted in negative controls. Immunohistochemical double-labeled preparations were examined using an Olympus BX40 microscope equipped for fluorescence (Olympus America, Melville, New York). Digital images were captured with an Optronics MagnaFire Camera (Optronics, Goleta, California) and channels were merged (Fig. 5) with MagnaFire software (Optronics).

\section{Note Added in Proof}

Clarijs et al (2002) recently described the conduction of fluid in laminin-positive looping patterns in a xenograft model of cutaneous and uveal melanoma and termed the patterns a "fluid-conducting meshwork."

\section{Transmission Electron Microscopy}

For transmission electron microscopy studies, tissue from three primary human uveal choroidal and ciliary body melanomas was fixed immediately after enucleation in $4 \%$ buffered glutaraldehyde and was postfixed in osmium tetroxide. After dehydration in ethanol and propylene, tissues were embedded in Epon. The tissue samples were microdissected under magnification to identify areas that showed a lobular organization suggestive of the presence of PAS-positive matrix patterns. One-micron sections were cut from at least 15 regions of each tumor and stained with toluidine blue. Specimens were examined by light microscopy to identify the presence of matrix patterns. Ultrathin sections stained with uranyl acetate and lead citrate were examined with a Philips EM410 transmission electron microscope (Philips, Eindhoven, The Netherlands). Each electron micrograph was coded as corresponding to a pattern detected on one-micron sections, and maps of the patterns were reconstructed by fashioning montages of electron micrographs.

\section{Acknowledgements}

We gratefully acknowledge the participation of Dr. Karla J.Daniels in the development of some of the cell lines used in this study. TNP-470 was a gift from Dr. Krysztoff Bojanowski and Dr. Donald Ingber. We also appreciate the helpful suggestions and comments offered by Drs. Mary J. C. Hendrix and E. Helene Sage.

\section{References}

Baron JA, Monzon F, Galaria N, and Murphy GF (2000). Angiomatoid melanoma: A novel pattern of differentiation in invasive periocular desmoplastic malignant melanoma. Hum Pathol 31:1520-1522.

Broze GJ Jr (1995). Tissue factor pathway inhibitor and the revised theory of coagulation. Annu Rev Med 46:103-112.

Chang YS, di Tomaso E, McDonald DM, Jones R, Jain RK, and Munn LL (2000). Mosaic blood vessels in tumor: Frequency of cancer cells in contact with flowing blood. Proc Natl Acad Sci U S A 97:14608-14613. 
Chen CS, Mrksich M, Huang S, Whitesides GM, and Ingber DE (1997). Geometric control of cell life and death. Science 276:1425-1428.

Clarijs R, Otte-Holler I, Ruiter DJ, and de Waal RM (2002). Presence of a fluid-conducting meshwork in xenografted cutaneous and primary human uveal melanoma. Invest Ophthalmol Vis Sci 43:912-918.

Clarijs R, Schalkwijk L, Ruiter DJ, and de Waal RMW (2001). Lack of lymphangiogenesis despite coexpression of VEGF-C and its receptor Flt-4 in uveal melanoma. Invest Ophthalmol Vis Sci 42:1422-1428.

Fischer EG, Riewald M, Huang HY, Miyagi Y, Kubota Y, Mueller BM, and Ruf W (1999). Tumor cell adhesion and migration supported by interaction of a receptor-protease complex with its inhibitor. J Clin Invest 104:1213-1221.

Folberg R, Hendrix MJ, and Maniotis AJ (2000). Vasculogenic mimicry and tumor angiogenesis. Am J Pathol 156:361-381.

Folberg R, Mehaffey M, Gardner LM, Meyer M, Rummelt V, and Pe'er J (1997). The microcirculation of choroidal and ciliary body melanomas. Eye 11:227-238.

Folberg R, Rummelt V, Parys-Van Ginderdeuren R, Hwang T, Woolson RF, Pe'er J, and Gruman LM (1993). The prognostic value of tumor blood vessel morphology in primary uveal melanoma. Ophthalmology 100:1389-1398.

Folkman J (1995). Seminars in medicine of the Beth Israel Hospital, Boston: Clinical applications of research on angiogenesis. N Engl J Med 333:1757-1763.

Folkman J (1996). New perspectives in clinical oncology from angiogenesis research. Eur J Cancer 32A:2534-2539.

Folkman J (2001). Can mosaic tumor vessels facilitate molecular diagnosis of cancer? Proc Natl Acad Sci USA 98:398 400.

Folkman $\mathrm{J}$ and Moscona A (1978). Role of cell shape in growth control. Nature 273:345-349.

Folkman J, Watson K, Ingber D, and Hanahan D (1989). Induction of angiogenesis during the transition from hyperplasia to neoplasia. Nature 339:58-61.

Frankel A, Buckman R, and Kerbel RS (1997). Abrogation of Taxol-induced G2-M arrest and apoptosis in human ovarian cancer cells grown as multicellular tumor spheroids. Cancer Res 57:2388-2393.

Hammersen F, Endrich B, and Messmer K (1985). The fine structure of tumor blood vessels. I. Participation of nonendothelial cells in tumor angiogenesis. Int $\mathrm{J}$ Microcirc Clin Exp 4:31-43.

Hendrix MJ, Seftor EA, Seftor RE, and Fidler IJ (1987). A simple quantitative assay for studying the invasive potential of high and low human metastatic variants. Cancer Lett 38:137-147.

Hendrix MJC, Seftor EA, Chu YW, Trevor KT, and Seftor REB (1996). Role of intermediate filaments in migration, invasion and metastasis. Cancer Met Rev 15:507-525.

Hendrix MJC, Seftor EA, Seftor REB, Gardner LM, Boldt HC, Meyer M, Pe'er J, and Folberg R (1998). Regulation of uveal melanoma interconverted phenotype by hepatocyte growth factor/scatter factor (HGF/SF). Am J Pathol 152:855-863.

Holash J, Maisonpierre PC, Compton D, Boland P, Alexander CR, Zagzag D, Yancopoulos GD, and Wiegand SJ (1999).
Vessel cooption, regression, and growth in tumors mediated by angiopoietins and VEGF. Science 284:1994-1998.

Ingber D, Fujita T, Kishimoto S, Sudo K, Kanamaru T, Brem $\mathrm{H}$, and Folkman $\mathrm{J}$ (1990). Synthetic analogues of fumagillin that inhibit angiogenesis and suppress tumour growth. Nature 348:555-557.

Ingber DE, Dike L, Hansen L, Karp S, Liley H, Maniotis A, McNamee H, Mooney D, Plopper G, and Sims J (1994). Cellular tensegrity: Exploring how mechanical changes in the cytoskeleton regulate cell growth, migration, and tissue pattern during morphogenesis. Int Rev Cytol 150:173-224.

Ingber DE and Folkman J (1989). Mechanochemical switching between growth and differentiation during fibroblast growth factor-stimulated angiogenesis in vitro: Role of extracellular matrix. J Cell Biol 198:317-330.

Ingber DE, Madri JA, and Folkman J (1987). Endothelial growth factors and extracellular matrix regulate DNA synthesis through modulation of cell and nuclear expansion. $\mathrm{J}$ In Vitro Cell Dev Biol 23:387-394.

Kan-Mitchell J, Mitchell MS, Rao N, and Liggett PE (1989). Characterization of uveal melanoma cell lines that grow as xenografts in rabbit eyes. Invest Ophthalmol Vis Sci 30:829834.

Konerding MA, Steinberg F, and Budach V (1989a). The vascular system of xenotransplanted tumors: Scanning electron and light microscopic studies. Scanning Microsc 3:327335.

Konerding MA, Steinberg F, and Streffer C (1989b). The vasculature of xenotransplanted human melanomas and sarcomas on nude mice. Acta Anat 136:21-26.

Kusaka M, Sudo K, Matsutani E, Kozai Y, Marui S, Fujita T, Ingber D, and Folkman J (1994). Cytostatic inhibition of endothelial cell growth by the angiogenesis inhibitor TNP470 (AGM-1470). Br J Cancer 69:212-216.

Levi-Montalcini R, Caramia F, Luse SA, and Angeletti PU (1968). In vitro effects of the nerve growth factor on the fine structure of the sensory nerve cells. Brain Res 8:347-362.

Levine JM and Nishiyama A (1996). The NG2 chondroitin sulfate proteoglycan: A multifunctional proteoglycan associated with immature cells. Perspect Dev Neurobiol 3:245-259.

Makitie T, Summanen P, Tarkannen A, and Kivela T (1999a). Microvascular loops and networks as prognostic indicators in choroidal and ciliary body melanomas. J Natl Cancer Inst 91:359-367.

Makitie T, Summanen P, Tarkkanen A, and Kivela T (1999b). Microvascular density in predicting survival of patients with choroidal and ciliary body melanoma. Invest Ophthalmol Vis Sci 40:2471-2480.

Maniotis A, Chen C, and Ingber D (1997). Demonstration of mechanical interconnections between integrins, cytoskeletal filaments, and nuclear scaffolds that stabilize nuclear structure. Proc Nat Acad Sci USA 94:849-854.

Maniotis AJ, Folberg R, Hess A, Seftor EA, Gardner LMG, Pe'er J, Trent JM, Meltzer PS, and Hendrix MJC (1999). Vascular channel formation by human melanoma cells in vivo and in vitro: Vasculogenic mimicry. Am J Pathol 155:739752 .

McLean IW, Keefe KS, and Burnier MN (1997). Uveal melanoma: Comparison of the prognostic value of fibrovas- 
cular loops, mean of the ten largest nucleoli, cell type and tumor size. Ophthalmology 104:777-780.

Nagy JA, Brown LF, Senger DR, Lanir N, Van De WL, Dvorak AM, and Dvorak HF (1989). Pathogenesis of tumor stroma generation: A critical role for leaky blood vessels and fibrin deposition. Biochim Biophys Acta 948:305-326.

Nasu R, Kimura H, Akagi K, Murata T, and Tanaka Y (1999). Blood flow influences vascular growth during tumour angiogenesis. Br J Cancer 79:780-786.

Neaud V, Hisaka T, Monvoisin A, Bedin C, Balabaud C, Foster DC, Desmouliere A, Kisiel W, and Rosenbaum J (2000). Paradoxical pro-invasive effect of the serine proteinase inhibitor tissue factor pathway inhibitor-2 on human hepatocellular carcinoma cells. J Biol Chem 275:3556535569.

Nicosia RF, Lin YJ, Hazelton D, and Qian X (1997). Endogenous regulation of angiogenesis in the rat aorta model: Role of vascular endothelial growth factor. Am J Pathol 151:13791386.

Potgens AJG, Lubsen NH, Vanaltena MC, Schoenmakers JGG, Ruiter DJ, and Dewaal RMW (1995). Vascular permeability factor expression influences tumor angiogenesis in human melanoma lines xenografted to nude mice. Am J Pathol 146:197-209.

Potgens AJG, van Altena MC, Lubsen NH, Ruiter DJ, and de Waal RMW (1996). Analysis of the tumor vasculature and metastatic behavior of xenografts of human melanoma cell lines transfected with vascular permeability factor. Am J Pathol 148:1203-1217.

Prause JU and Jensen OA (1980). Scanning electron microscopy of frozen-cracked, dry-cracked and enzyme-digested tissue of human malignant choroidal melanomas. Albrecht Von Graefes Arch Klin Exp Ophthalmol 212:217-225.

Rummelt V, Folberg R, Rummelt C, Gruman LM, Hwang T, Woolson RF, Yi H, and Naumann GOH (1994). Microcirculation architecture of melanocytic nevi and malignant melanomas of the ciliary body and choroid: A comparative histopathologic and ultrastructural study. Ophthalmology 101: 718-727.

Rummelt V, Mehaffey MG, Campbell RJ, Peer J, Bentler SE, Woolson RF, Naumann GOH, and Folberg R (1998). Microcirculation architecture of metastases from primary ciliary body and choroidal melanomas. Am J Ophthalmol 126:303305.

Sakamoto T, Sakamoto M, Yoshikawa H, Hata Y, Ishibashi T, Ohnishi $Y$, and Inomata H (1996). Histologic findings and prognosis of uveal malignant melanoma in Japanese patients. Am J Ophthalmol 121:276-283.

Seftor EA, Meltzer PS, Kirschmann DA, Pe'er J, Maniotis AJ, Trent JM, Folberg R, and Hendrix MJC (2002). Molecular determinants of uveal melanoma metastasis. Clin Exp Metastasis 19:233-246.

Seftor REB, Seftor EA, Koshikawa N, Meltzer PS, Gardner LMG, Bilban M, Stetler-Stevenson WG, Quaranta V, and Hendrix MJC (2001). Cooperative interactions of laminin 5 2 chain: Matrix metalloproteinase-2, and membrane type-1matrix/metalloproteinase are required for mimicry of embryonic vasculogenesis by aggressive melanoma. Cancer Res 61:6322-6327.
Seregard S, Spangberg B, Juul C, and Oskarsson M (1998). Prognostic accuracy of the mean of the largest nucleoli, vascular patterns, and PC-10 in posterior uveal melanoma. Ophthalmology 105:485-491.

Shirakawa K, Kobayashi H, Heike Y, Kawamoto S, Brechbiel MW, Kasumi F, Iwanaga T, Konishi F, Terada M, and Wakasugi $H$ (2002). Hemodynamics in vasculogenic mimicry and angiogenesis of inflammatory breast cancer xenograft. Cancer Res 62:560-566.

Shirakawa K, Tsuda H, Heike Y, Kato K, Asada R, Inomata M, Sasaki H, Kasumi F, Yoshimoto M, Iwanaga T, Konishi F, Terada M, and Wakasugi $H$ (2001). Absence of endothelial cells, central necrosis, and fibrosis are associated with aggressive inflammatory breast cancer. Cancer Res 61:445451.

Singhvi R, Lopez GP, Stephanopoulos GN, Wang DI, Whitesides GM, and Ingber DE (1994). Engineering cell shape and function. Science 264:696-698.

Sood AK, Seftor EA, Fletcher MS, Gardner LMG, Heidger PM, Buller RE, Seftor REB, and Hendrix MJC (2001). Molecular determinants of ovarian cancer plasticity. Am J Pathol 158:1279-1288.

Straume O and Akslen LA (2001). Expression of vascular endothelial growth factor, its receptors (FLT-1, KDR) and TSP-1 related to microvessel density and patient outcome in vertical growth phase melanomas. Am J Pathol 159:223-235.

Strohman RC, Bayne E, Spector D, Obinata T, MicouEastwood J, and Maniotis A (1990). Myogenesis and histogenesis of skeletal muscle on flexible membranes in vitro. In Vitro Cell Dev Biol 25:201-208.

Thies A, Mangold U, Moll I, and Schumacher U (2001). PAS-positive loops and networks as a prognostic indicator in cutaneous malignant melanoma. J Pathol (195):537-542.

Thompson WD, Shiach KJ, Fraser RA, McIntosh LC, and Simpson JG (1987). Tumours acquire their vasculature by vessel incorporation, not vessel ingrowth. J Pathol 151:323332.

Timar J and Toth J (2000). Tumor sinuses: Vascular channels. Pathol Oncol Res 6:83-86.

Vernon RB, Angello JC, Iruela-Arispe ML, Lane TF, and Sage EH (1992). Reorganization of basement membrane matrices by cellular traction promotes the formation of cellular networks in vitro. Lab Invest 66:536-547.

Vernon RB, Lara SL, Drake CJ, Iruelaarispe ML, Angello JC, Little CD, Wight TN, and Sage EH (1995). Organized type I collagen influences endothelial patterns during "spontaneous angiogenesis in vitro": Planar cultures as models of vascular development. In Vitro Cell Dev Biol Anim 31:120-131.

Warso MA, Maniotis AJ, Chen X, Majumdar D, Patel MK, Shilkaitis A, Gupta TK, and Folberg R (2001). Prognostic significance of periodic acid-Schiff-positive patterns in primary cutaneous melanoma. Clin Cancer Res 7:473-477.

Weidner N (1998). Tumoral vascularity as a prognostic factor in cancer patients: The evidence continues to grow. J Pathol 184:119-122. 